\title{
The Level of Occlusion of Included Bark Affects the Strength of Bifurcations in Hazel (Corylus avellana L.)
}

\section{Duncan Slater and Roland Ennos}

\begin{abstract}
Bark-included junctions in trees are considered a defect as the bark weakens the union between the branches. To more accurately assess this weakening effect, 241 bifurcations from young specimens of hazel (Corylus avellana L.), of which 106 had bark inclusions, were harvested and subjected to rupture tests. Threepoint bending of the smaller branches acted as a benchmark for the relative strength of the bifurcations.

Bifurcations with included bark failed at higher displacements, and their modulus of rupture was $24 \%$ lower than normally formed bifurcations, while stepwise regression showed that the best predictors of strength in these bark-included bifurcations were the diameter ratio and width of the bark inclusion, which explained $16.6 \%$ and $8.1 \%$ of the variability, respectively. Cup-shaped, bark-included bifurcations where included bark was partially occluded by xylem were found, on average, to be $36 \%$ stronger than those, where included bark was situated at the bifurcation apex.

These findings show that there are significant gradations in the strength of bark-included bifurcations in juvenile hazel trees that relate directly to the level of occlusion of the bark into the bifurcation. It therefore may be possible to assess the extent of the defect that a bark-included bifurcation represents in a tree by assessing the relative level of occlusion of the included bark.

Key Words. Bifurcation; Corylus avellana; Hazel; Included Bark; Rupture Tests; Three-Point Bending.
\end{abstract}

Junctions in trees that are separated by bark being included in their union are frequently found in urban and forest trees (Lonsdale 1999). Such junctions have a reputation of being structural flaws in tree crowns (Shigo 1989; Lonsdale 2000; Harris et al. 2004; Gilman 2011), and they are commonly recorded as a defect by tree assessors and others with responsibility for the safety of people and property adjacent to trees (Matheny and Clark 1994; Mattheck and Breloer 1994).

Where only two branches arise from a junction in a tree, this is formally referred to as a bifurcation. It has been established that the diameter ratio' between the two branches that arise from a bifurcation in a tree has a substantial effect on its mechanical strength and failure mode (Gilman 2003). The diameter ratio is defined as the ratio between the basal diameters of the smaller and larger branch, measured just above the point of their attachment to each other at the bifurca- tion; this is also often referred to as the aspect ratio (Gilman 2003). Kane et al. (2008), through rupture testing, found that bifurcations formed in young trees of three species (i.e., Acer rubrum L., Quercus acutissima Carruthers, and Pyrus calleryana Decne.) that had a diameter ratio of $70 \%$ or higher were only half as strong as those that had a clearly subsidiary branch. Additionally, these researchers found that the fracture surfaces of bifurcations with a low diameter ratio showed that xylem tissues of the smaller branch were embedded within the larger branch; in contrast, codominant stems exhibited relatively flat fracture surfaces with little to no embedding of tissues.

Two distinct failure modes occur in higher diameter ratio bifurcations of hazel (Corylus avellana L.) when subjected to tensile loading. These have been defined by Slater and Ennos (2013) as Type I and Type II failure modes. In the Type I failure mode, which tends to occur at intermediate diameter 
ratios $(70 \%$ to $80 \%)$, there is compressive yielding of the xylem at the base of the smaller branch at its outer edge, before the bifurcation splits at its apex (Figure 1a). In the Type II failure mode, which occurs most often when the two branches are nearer to the same diameter (diameter ratios $>80 \%$ ), there is no compressive yielding and the bifurication fails by a sudden splitting at its apex (Figure 1b). In much lower diameter ratio bifurcations $(<70 \%)$, yielding of the branch under compression then tearing of its tissues under tension near the bifurcation becomes a common mode of failure (Figure 1c), which is termed a 'branch failure'.

The strength of a normally formed hazel bifurcation can be considered to be provided by three components: the resistance of wood at the center of the join to tension, the resistance of wood at either side of the center of the join to tension, and the bending resistance of the wood at the side of the smaller branch as it joins the other branch. The tensile strength of a bifurcation in a tree is increased by it having a zone of interlocking wood grain in the center of the join (Slater and Ennos 2013; Slater et al. 2014).

Once bark is included into a bifurcation, it is inherently weakened, as the centrally placed interlocking wood grain is absent at the apex (Slater et al. 2014). Smiley (2003) found that young tree bifurcations with bark inclusions in Acer rubrum L. were $20 \%$ weaker when pulled apart than those without bark inclusions. A bifurcation with included bark may not remain a significant defect as it matures; it may develop in ways that affect both the relative size of the bark inclusion and the shape of the bifurcation overall. A bifurcation may grow to completely occlude the bark inclusion (Figure 2a), so it is invisible from the outside; it may form additional xylem around and above the bark inclusion without fully occluding it (Figure $2 \mathrm{~b}$ ); or the bark inclusion may persist and remain at roughly the same proportion of the width of the join with every annual increment of growth (Figure 2c).

In arboricultural guidance on this commonly occurring structural flaw, Lonsdale (2000) suggests that the length of the bark inclusion that is visible along the branch bark ridge below the apex of a bifurcation may be linked to the likelihood of its failure. Helliwell (2004) has also suggested that there may be an influence on the strength of a bifurcation with included bark from the degree of constriction of the parent stem's diameter just below the apex of the bifurcation where the bark inclusion starts. Kane et al. (2008) found the percentage area of the fractured attachment covered by a bark inclusion in red maple (Acer rubrum), sawtooth oak (Quercus acutissima), and Callery pear (Pyrus calleryana) did not reliably predict the strength of the bifurcation, but that overall the strength of bark-included bifurcations was lower than normally formed bifurcations.

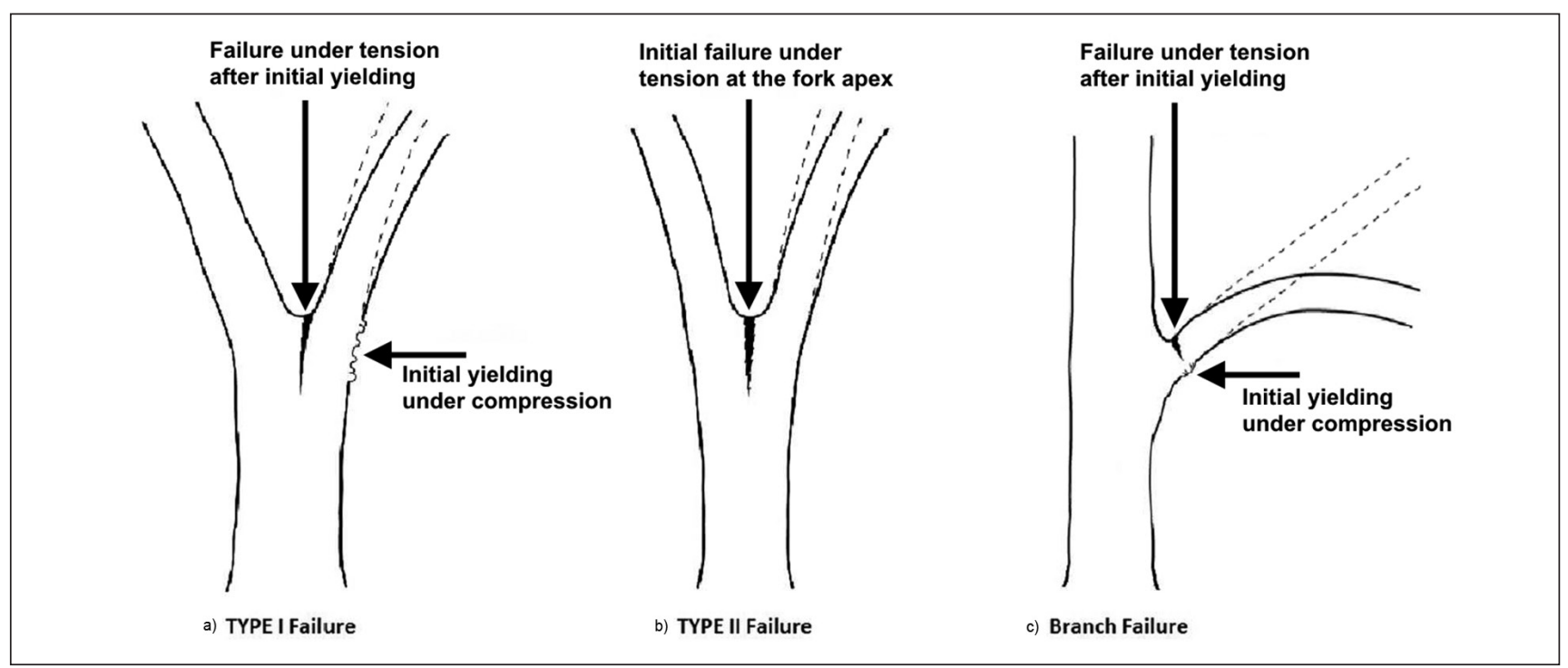

Figure 1. Type I and Type II and branch failure modes of tree bifurcations under tension across the bifurcation. In Type I failure mode, the xylem yields initially under compressive forces on the outer edge of the bifurcation before the bifurcation splits at its apex under tension. In Type II failure mode the initial failure is under tension at the bifurcation apex. In branch failures, the initial failure is compressive buckling of the xylem on the underside of the branch before the top of the branch is torn apart under tension. 


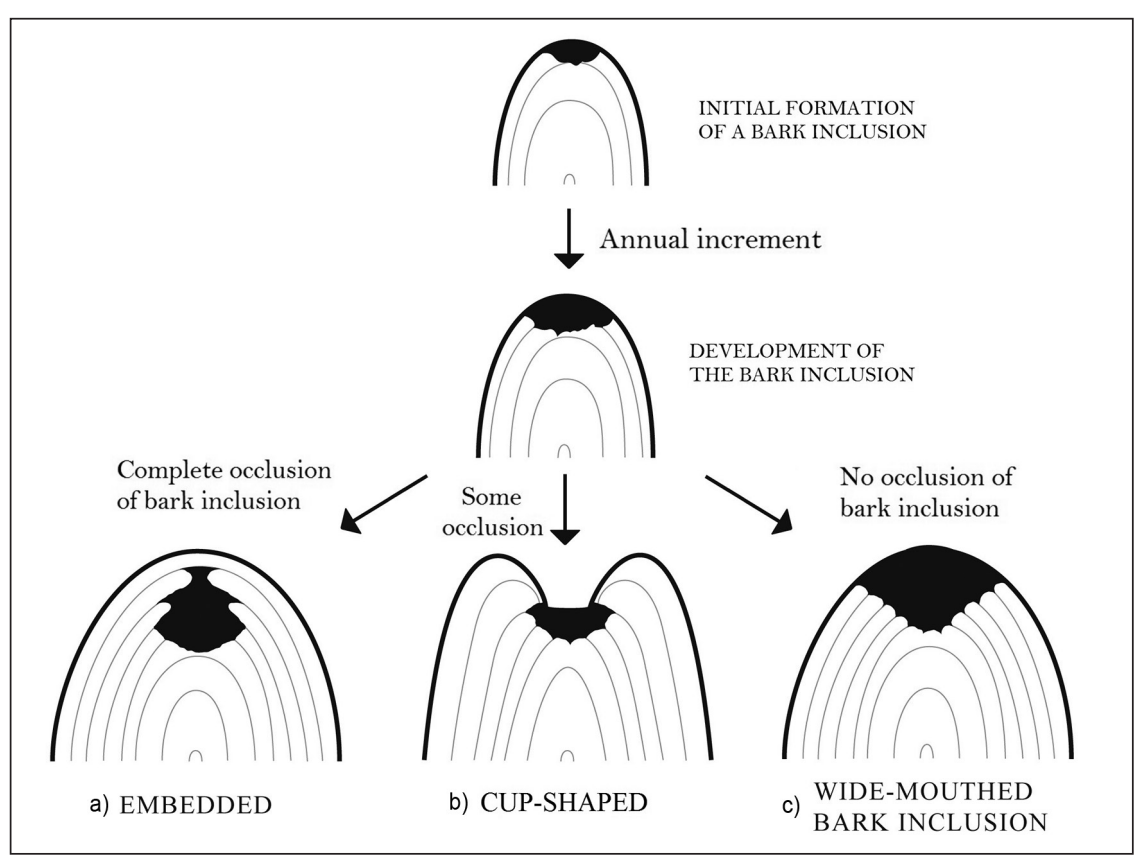

Figure 2. Potential development pathways for a bark inclusion, showing the morphology of the xylem perpendicular to the plane of the bifurcation, leading to the formation of (a) embedded bark, b) a cup-shaped bifurcation, or c) a wide-mouthed bark inclusion.

Despite these general observations by experienced researchers, there are no current means of quantifying the heightened risk of failure of bifurcations with included bark in trees from observing their external morphology or the position and size of the bark inclusion present. In this study, therefore, researchers investigated the strength of bifurcations in relation to the presence or absence of bark inclusions, and, if present, the position, shape, and size of bark inclusions found. The authors sought to find a simple rule by which the relative weakness of a bifurcation with included bark could be predicted.

The authors chose to model this mechanical behavior in one species, Corylus avellana L., as similar research on this species has been carried out by Pfisterer (2003), which allows for a comparison in findings, and the wood grain orientation and mechanical contributions of different components of such bifurcations in this species have recently been uncovered (Slater and Ennos 2013). This species was favored as an experimental subject because it provides a sustainable source of bifurcations, and because working with coppice-grown material of one species limits the effects of other factors (e.g., age differences, differences in levels of exposure) that could affect bifurcation strength. Having a more comprehensive picture of the biomechanics of bifurcations in one woody species, which has been well researched with respect to its anatomy and mechanical behavior, justifies the single species choice in this study.

Testing the strength of young tree bifurcations may provide useful insight for tree assessors as they inspect larger-growing tree species with bark-included junctions, although this approach will likely have its limitations in terms of the scale of the tree bifurcations tested. An important limitation to consider is that young tree bifurcations will consist mostly of juvenile wood, whose mechanical behavior is different from wood in mature tree boughs. It would therefore be errant to assume that findings from testing young bifurcations could be directly applied to the much larger bifurcations of mature trees.

\section{MATERIALS AND METHODS}

Between November 2010 and January 2012, 241 junctions of hazel were harvested from a hazel coppice situated at Prestwich Country Park, Manchester, UK. All the junctions harvested had two emergent branches, making each one a 'bifurcation' Collecting from only one site was necessary to limit the number of factors affecting bark inclusion formation and bifurcation strength. For example, if one collected from more exposed and more sheltered locations, then the strength of the individual bifurcations within the sample would vary much more widely. Collection of the samples was randomized throughout the coppice, avoiding obtaining more than two bifurcations from any one tree and not taking any bifurcations from trees growing along the edges of the coppice. This resulted in 96 samples being collected from the same tree as one other sample, and 145 samples each being the only one collected from a particular tree.

Samples were cut to retain approximately 100 $\mathrm{mm}$ of the parent stem and $215 \mathrm{~mm}$ of each branch arising from the bifurcation. Samples were wrapped separately in plastic bags and put in cold storage at $2^{\circ} \mathrm{C}-3^{\circ} \mathrm{C}$ to reduce sap loss before testing. The hazel bifurcations had an average parent stem diameter 
of $33.2 \mathrm{~mm}$ (range $17.01 \mathrm{~mm}$ to $58.69 \mathrm{~mm}$ ) and an age range of between three- and eight-years-old

Rupture tests were carried out to measure the breaking stress of each bifurcation collected. A $6 \mathrm{~mm}$ hole was drilled in both arising branches of each bifurcation, approximately $200 \mathrm{~mm}$ from the apex of, and perpendicular to, the plane of the bifurcation. Each of these specimens was then attached via these drill holes to the crosshead and base of an Instron ${ }^{\circledR} 4301$ Universal Testing Machine (UTM) mounted with a $1 \mathrm{kN}$ load cell, and then subjected to a rupture test, with the crosshead moving upwards at $30 \mathrm{~mm} \mathrm{~min}^{-1}$. An interfacing computer recorded the displacement (in millimeters) and peak load (in Newtons) at a data rate of ten measurement points per second.

The failure mode was observed closely and recorded for each specimen during this test procedure. The Type I failure mode was categorized by the appearance of ripples caused by compression forces on the outer edge of the smaller branch as it joined the bifurcation, prior to the splitting of the bifurcation apex. Specimens recorded as undergoing Type II failure mode exhibited no compressive yielding in the exterior tissues prior to the bifurcation splitting at its apex. Branch failures were categorized as all those failures that occurred in the arising branch and did not split the bifurcation apart (Figure 1).

The following dimensions of each sample were then measured using a metal rule and digital calipers: the diameter proximal to the bifurcation of the parent stem (PS), at the base of the branch bark ridge; the diameter of the larger and smaller arising branches in line with, and perpendicular to, the plane of the bifurcation $(A 1, A 2, B 1$, and $B 2)$; and the distances between the drill holes $(a)$, and between each drill hole and the bifurcation apex ( $b$ and $c$ ) (Figure 3). Together with the peak force and displacement readings from the UTM, these parameters were used to calculate the maximum bending moment and bending stress for each sample tested.

The maximum bending moment $\left(M_{\max }\right)$ required to break each bifurcation was calculated using the equation:

$$
M_{\max }=F_{\text {peak }} b \operatorname{Sin} \alpha
$$

where $F_{\text {peak }}$ is the peak force, $b$ is the length between the drill hole in the smaller branch of the specimen to the mid-point of the base of

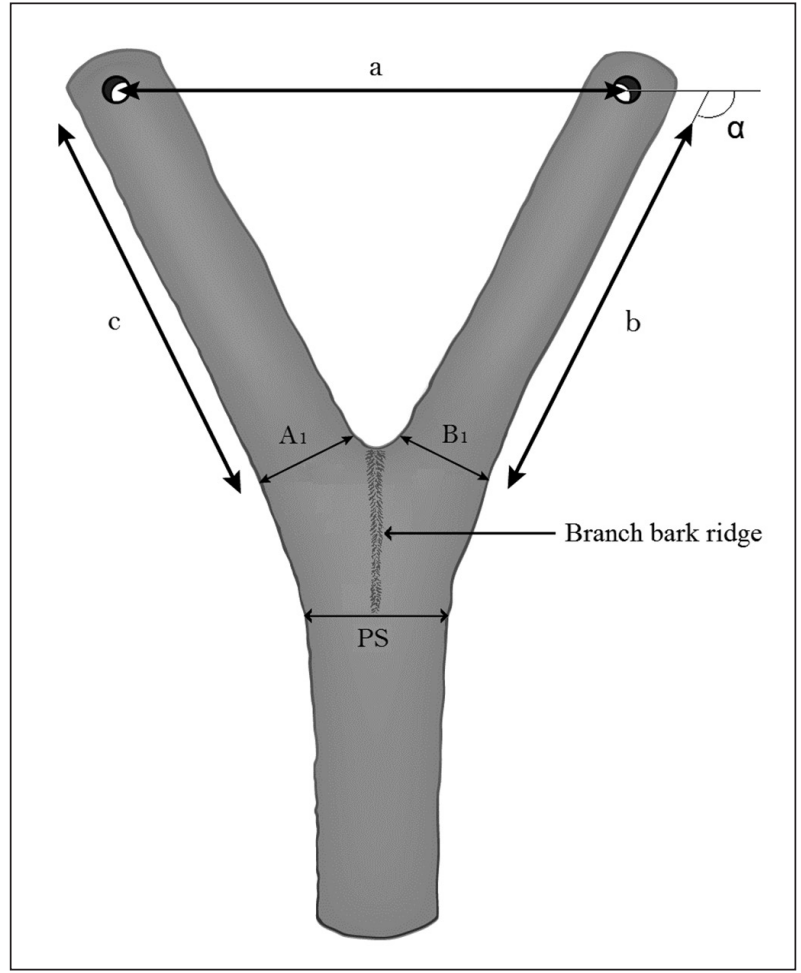

Figure 3. Measurements taken of the sample bifurcations with digital calipers and a metal rule: The diameter of the parent stem (PS) and the diameters of both arising branches proximal to the bifurcation in the plane of the bifurcation (A1 and $\mathrm{B} 1$ ) and the distances between the drill holes and the bifurcation apex (a, b, and $c)$. The diameters of both arising branches were also measured perpendicular to the plane of the bifurcation, giving values A2 and B2.

the smaller branch at the apex of the bifurcation, and $\alpha$ is the angle at which the force is applied relative to the bearing of length $b$ (Figure 3).

The angle $\alpha$ was calculated in degrees using the formula:

$$
\alpha=\operatorname{Cos}^{-1} \frac{(a+e x t)^{2}+b^{2}-c^{2}}{2(a+e x t) b}
$$

where $(a+$ ext $)$ is the distance between the two drilled holes in the two members of the bifurcation at the point when peak force was recorded, $b$ is the distance between the drill hole in the smaller branch and the apex of the branch bark ridge and $c$ is the distance between the drill hole in the larger branch and the apex of the branch bark ridge (Figure 3).

To normalize the bending strength of the bifurcations in relation to their different sizes, the maximum bending moment was divided by the section modulus of the elliptical cross section of the smaller branch of the bifurcation at its point of attachment. 
The result is maximum bending stress $\left(\sigma_{\text {fmax }}\right)$ for each bifurcation and was calculated using the equation:

$$
\sigma_{f \max }=\frac{32 M_{\max }}{\pi B_{1}^{2} B_{2}}
$$

where $B_{1}$ and $B_{2}$ are two diameters of the smaller branch at its base, taken respectively in line with, and perpendicular to, the plane of the bifurcation (Gere and Timoshenko 1996).

After the rupture testing, a three-point bending test was carried out on the smaller of the branches arising from the bifurcation to determine the bending stress it could withstand before yielding. All branches were carefully checked to verify they had not been damaged during the rupture testing prior to this three-point bending. This ensured reliable results during testing. This second test was done to allow for comparison between branch strength and bifurcation strength based on estimations of yield stresses at the base of the smaller branches during the rupture tests (Equation 3) and at the middle of the smaller branches during the three-point bending tests (Equation 4). Limitations of the load cell available meant that branches above the diameter of 23 $\mathrm{mm}$ could not be bent to their yield point, limiting the sample size for this second test to 83 branches.

In this three-point bending test, the smaller branch was placed upon steel supports set 295 $\mathrm{mm}$ apart, and a semicircular plastic probe of 30 $\mathrm{mm}$ diameter, attached to a $1 \mathrm{kN}$ load cell in the crosshead of the testing machine, was lowered until it was in contact with the middle of the supported branch. The span length available for these tests was necessarily limited to $295 \mathrm{~mm}$ because of the location of two side columns on the UTM. The testing machine's crosshead was then driven downward at a rate of $35 \mathrm{~mm} \mathrm{~min}^{-1}$, bending the branch until it failed, while an interfacing computer recorded a graph of force versus displacement. This loading rate has been successfully used in previous experiments of this nature (van Casteren and Ennos 2010; Slater and Ennos 2013).

This test was used to calculate the maximum bending stress $\left(\sigma_{\text {bmax }}\right)$ acting upon the branch before it yielded using the equation:

[4] $\quad \sigma_{\text {bmax }}=\frac{8 P_{\max } L_{\text {span }}}{\pi D_{\text {mid }}{ }^{2} W_{\text {mid }}}$ where $P_{\max }$ was the maximum load and $L_{\text {span }}$ was the distance between the supports, $D_{\text {mid }}$ and $W_{\text {mid }}$ were the diameters of the branch in line with, and perpendicular to, the load, respectively, and measured where the plastic probe was in contact with the branch during the test (Gere and Timoshenko 1996).

The completion of the rupture tests and threepoint bending tests allowed for comparison between the maximum bending stresses of the bifurcations tested with the maximum bending stresses of the smaller branches that arose from these bifurcations.

\section{MORPHOLOGICAL MEASUREMENTS}

\section{Measurements of Included Bark}

For all the bifurcations where bark inclusions were exposed during the rupture testing $(\mathrm{n}=104)$, the fracture surfaces were then excised and digitally scanned using an HP Scanjet $2400^{\circ}$ (Hewlett Packard, Palo Alto, California, U.S.). These samples were then categorized as either embedded bark inclusions ( $\mathrm{n}=17$ ), cup unions $(\mathrm{n}=57)$, or wide-mouthed bark-included bifurcations $(\mathrm{n}=30)$ (Figure 2). The image analysis software Image ${ }^{\oplus}$ (Abramoff et al. 2004) was then used to measure the area of bark relative to that of the fracture surface (Figure 4a). The same technique was used to measure the ratio between the width of the bark inclusion at the apex of the bifurcation and the width of the parent stem at the base of the branch bark ridge, where the pith of the parent stem bifurcates (Figure 4b). This second measure was chosen as researchers suspected that as the highest tensile stresses act at the bifurcation apex when the two branches are pulled apart, so the failure would occur more easily when a higher proportion of included bark was present in this location.

The bifurcations with included bark that was exposed at the apex $(n=87)$ were also categorized as to whether they had formed a cup-like bifurcation (where two areas of xylem were found at the apex of the bifurcation, formed on either side and above the bark inclusion), or whether there was included bark situated at the apex of the bifurcation (Figure 5). Again, this comparison was chosen to try to assess if there was a difference in the strength of these two types of bark-included bifurcation because of the difference as to which material (wood or bark) was situated at the apex. 


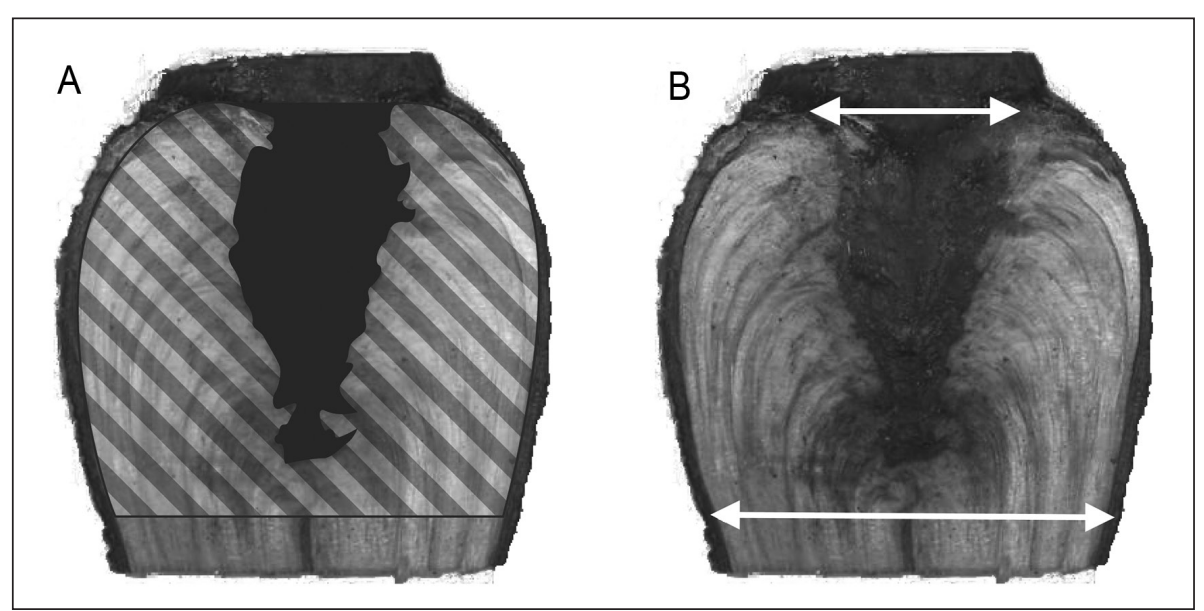

Figure 4. Measurements of the fracture surfaces of bark-included bifurcations carried out in ImageJ: a) proportion of the area of the fracture surface containing included bark; b) relative width of the bark inclusion at the apex of the bifurcation, when compared with the width of the parent stem, at the point where the pith bifurcates.

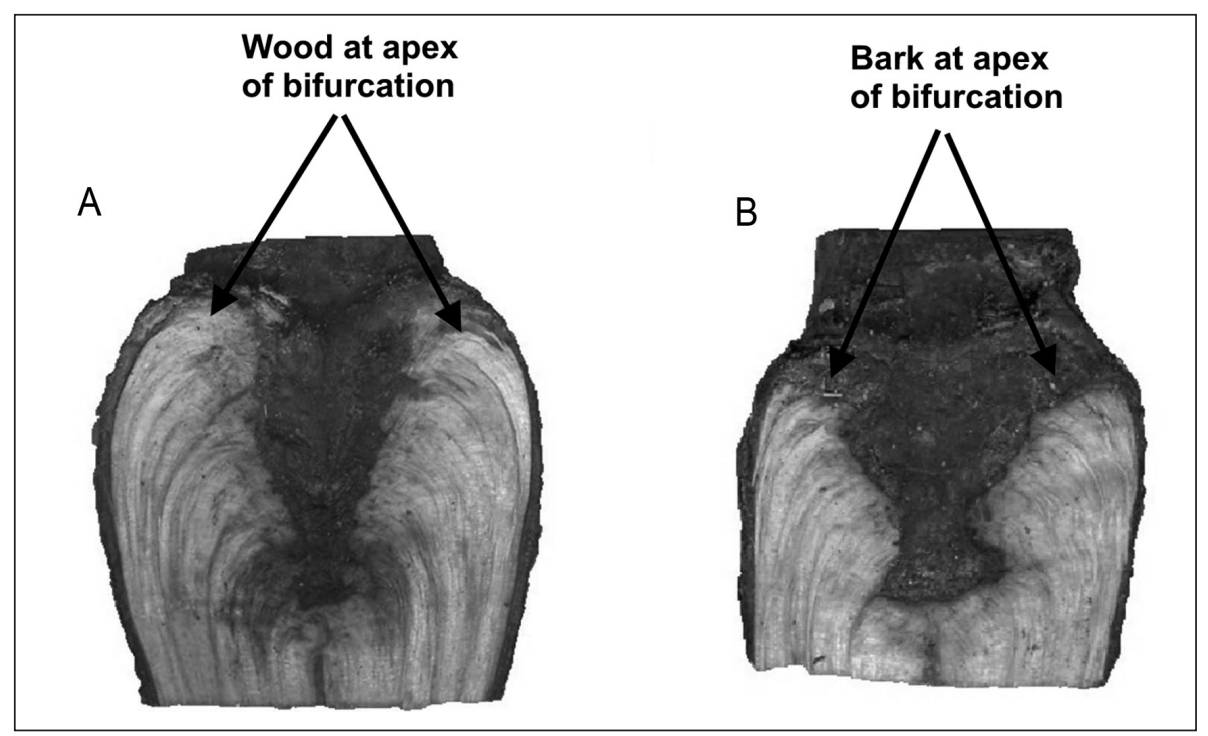

Figure 5. Simple visual categorization of bifurcations with included bark into two types so that their strength could be compared: a) cup-shaped bifurcation with wood at its apex, b) bifurcation with included bark at its apex.

\section{Statistical Analysis}

A $\chi^{2}$ test was used to determine if there was a significant difference in failure mode between bifurcations withincludedbarkand normally formedbifurcations.

To analyze the relationship between different failure modes observed and the diameter ratio of the samples tested, a GLM ANOVA was carried out with one covariate (the diameter of the parent stem) and with the random factor of the tree number from which each sample was collected. A post hoc Tukey test with $95 \%$ confidence interval was used to confirm statistical differences between groups of samples exhibiting different failure modes.

To analyze the relationship between the displacement of the sample prior to failing and the failure modes exhibited by the samples, a GLM ANOVA with post hoc Tukey test was used, with the diameter of the parent stem as covariate. A subsequent one-way ANOVA was used to determine if barkincluded bifurcations exhibiting a Type II failure mode had significantly shorter displacements before failure than normally formed bifurcations.

A one-way ANOVA, alongside a post hoc Tukey test with $95 \%$ confidence interval, was used to find differences in sample strength between normally formed bifurcations, bifurcations with included bark, and smaller arising branches.

The relationship between the maximum breaking stress $\left(\sigma_{\text {fmax }}\right)$ and the shape of the bark inclusions in the bifurcations with included bark exposed at their apex $(n=87)$ was investigated using stepwise regression analysis. Samples with embedded bark $(n=17)$ were excluded from this analysis as they did not have a width of bark at the apex of the bifurcation. These stepwise regressions were performed to identify the best models for predicting bifurcation strength from the parameters measured for each sample (e.g., the diameter ratio, the parent stem diameter, the proportional area of included bark on the fracture surface, and the ratio of the bark width at the bifurcation apex with the parent stem diameter).

A GLM ANOVA, alongside a post hoc Tukey test with $95 \%$ confidence interval, was used to confirm differences between groups of categorized bark-included bifurcations and normally 
formed bifurcations, again with the diameter of the parent stem as a covariate and with the number of the tree collected from as a random variable.

Residuals from these ANOVAs and regressions were tested for normality using the Anderson-Darling test to ensure the data were suitable for analysis by parametric statistical tests.

All statistical tests were carried out in Minitab $^{\odot} 16$ statistical software.

\section{RESULTS}

The range of diameter ratios found in the sample was from $53 \%$ to $100 \%$, with the mean ratio being $81.41 \% \pm 0.7$ SE. There was no significant difference in the average branch diameter ratio between bifurcations with or without included bark; diameter ratios of the two branches were $80.8 \% \pm 1.0 \mathrm{SE}$ for the normally formed bifurcations and $82.1 \% \pm 1.1$ SE for bifurcations with included bark. Neither did the two types of bifurcation show a significant difference in the relative incidences of the three failure modes $\left(\mathrm{X}_{2}^{2}=4.224 ; P=0.121\right.$ ) (Table $1)$; in both, Type II failure modes were commonest and branch failures least common.

A subsequent GLM ANOVA showed that there were significant differences between these three modes of failure due to difference in diameter ratio $\left(\mathrm{F}_{2,236}=6.28 ; \mathrm{p}=0.004\right)$; the parent stem diameter was not a significant covariant $\left(\mathrm{F}_{1,236}=3.82 ; P=0.057\right)$, and the random factor of the tree number was not significant $\left(\mathrm{F}_{192,236}=0.78 ; P=0.866\right)$. The higher the diameter ratio, the more common were Type II failure modes and the less common were Type I failure modes and branch failures. A post hoc Tukey test $(\mathrm{CI}=95 \%)$ confirmed that this difference was significant between the Type II failure mode and the other two failure modes observed (Figure 6).

Table 1. Instances of different failure modes experienced $(n)$ and associated average diameter ratios $(\mu)$ of control and bark-included forks subjected to tensile testing.

\begin{tabular}{llll}
\hline Specimen type & Branch failure & Type I failure & Type II failure \\
\hline Control & $\mathrm{n}=9$ & $\mathrm{n}=53$ & $\mathrm{n}=73$ \\
& $\mu=76 \%$ & $\mu=74 \%$ & $\mu=86 \%$ \\
Bark-included & $\mathrm{n}=6$ & $\mathrm{n}=29$ & $\mathrm{n}=71$ \\
junctions & $\mu=66 \%$ & $\mu=76 \%$ & $\mu=86 \%$ \\
\hline
\end{tabular}

Mean displacements of samples prior to yielding were $135.26 \mathrm{~mm} \pm 15.18 \mathrm{SE}$ for branch failures, $83.04 \mathrm{~mm} \pm 5.08 \mathrm{SE}$ for Type I failures, and $37.17 \mathrm{~mm} \pm 1.55 \mathrm{SE}$ for Type II failures. A GLM ANOVA identified a statistical difference between these three groups in terms of the extent of their displacement prior to yielding $\left(\mathrm{F}_{2,236}=89.59 ; P<0.001\right)$; the parent stem diameter was not a significant covariant $\left(\mathrm{F}_{1,236}=0.08\right.$; $P=0.774)$. A post hoc Tukey test $(\mathrm{CI}=95 \%)$ confirmed that this difference was significant between all three failure modes, identifying that branch failures occurred after the greatest displacement and Type II failure modes after the least displacement. The mean displacement for Type II failures of normally formed bifurcations was $43.32 \mathrm{~mm} \pm 2.29 \mathrm{SE}$, whereas the mean displacement for Type II failures of barkincluded bifurcations was $30.85 \mathrm{~mm} \pm 1.8 \mathrm{SE}$. Analysis of these specimens exhibiting Type II failure mode using a one-way ANOVA and post hoc Tukey test $(\mathrm{CI}=95 \%)$ found that barkincluded bifurcations had a smaller displacement before peak force was reached than the normally formed bifurcations $\left(\mathrm{F}_{1,142}=18.18 ; P<0.001\right)$.

Figure 7 shows typical examples of the force/ displacement graphs of the rupture tests on the hazel bifurcations that suffered the Type I and Type II failure modes in normally formed bifurcations, a typical branch failure and the typical failure of a bifurcation with included bark at its apex. It can be seen that a long phase of plastic yielding occurs in both branch failure and in Type I failure mode of bifurcations without included bark (Figure 7) with large subsequent deflections before the maximum force is reached. In contrast, in Type II failure mode, there is a sharp drop in force due to fracture after only a very short phase of yielding, while in the bifurcation with included bark, even though it is undergoing Type II failure mode, there is apparent plastic yield at a lower force and a more gradual reduction in force after failure.

The maximum stresses for the branches subjected to three-point bending tests $\left(\sigma_{b \max }\right)$, and for the normally formed bifurcations and those with included bark subjected to rupture tests $\left(\sigma_{\text {fmax }}\right)$, are shown in Figure 8. Bark included bifurcations were on average $24.3 \%$ weaker than ones 
without included bark, which were in turn $13.6 \%$ weaker than the smaller branch. A one-way ANOVA identified a significant difference in bending stresses for these three groups $\left(\mathrm{F}_{2,320}=112.25\right.$; $P<0.001)$, the residuals were found to be normally distributed $\left(\mathrm{AD}_{323}=0.402 ; P=0.358\right)$, and a post hoc Tukey test $(\mathrm{CI}=95 \%)$ confirmed that each group's mean yield stress was significantly different from the other groups.

\section{Effects of the Extent and Location of Included Bark}

The first regression model that identified a significant relationship used a combination of the diameter ratio $\left(\mathrm{t}_{84}=4.42 ; P<0.001\right)$ and the area of the bark inclusion $\left(\mathrm{t}_{84}=\right.$ 2.38; $P=0.02$ ). The overall model fit was $\mathrm{R}^{2}=0.21$, and the best fit line was given by the equation:

[5] Yield stress $(\mathrm{MPa})=69.9-$ $35.2 r-24.6 a$

where $r$ is the diameter ratio of the two branches of the bifurcation (as a percentage with a maximum of $100 \%)$ and $a$ is the area of bark as a percentage of the entire fracture surface (maximum value 100\%) from the point of the bifurcation of the pith to the apex. The diameter ratio predicted $15.8 \%$ of the variability in the sample, the area of the bark inclusion only a further 5.3\% using this model (Equation 5). When the factor of parent stem diameter was added to this regression model, it did not significantly improve the prediction of breaking strength $\left(\mathrm{t}_{83}=1.04 ; P=0.302\right)$.

The second regression model found to be significant using the stepwise regression approach identified a stronger relationship using a combination of the diameter ratio $\left(\mathrm{t}_{84}=4.57\right.$; $P<0.001)$ and width of bark inclusion $\left(\mathrm{t}_{84}=3.0\right.$;

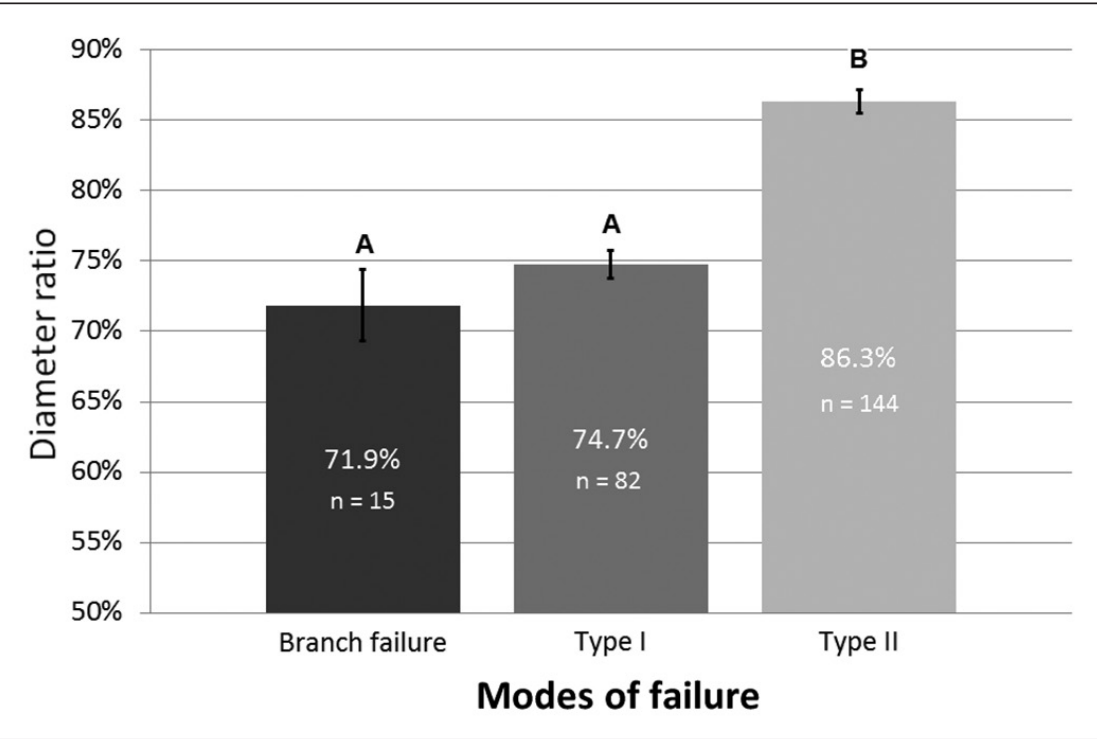

Figure 6. Failure modes in relation to the diameter ratio between the two branches of each bifurcation that underwent a rupture test. Letters above the bars mark heterogeneity in the sample groups, as determined by a GLM ANOVA and post hoc Tukey test with $95 \%$ confidence interval.

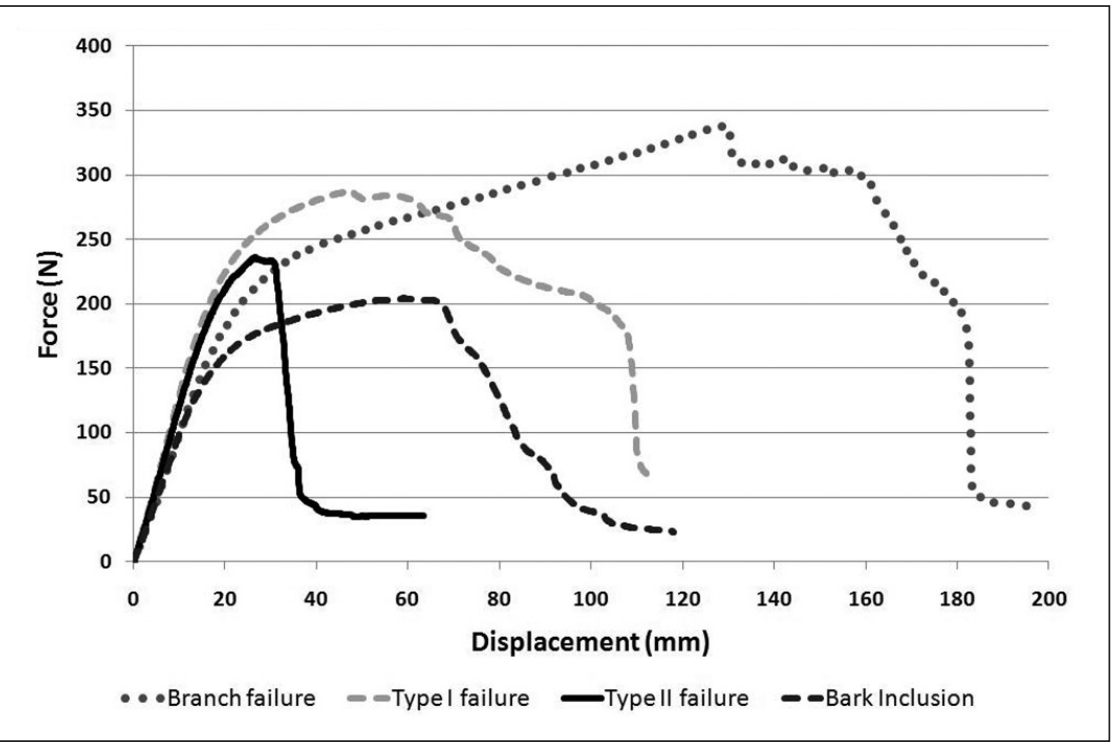

Figure 7. Typical force/displacement graph for specimen types.

$P=0.004)$. The overall model fit was $\mathrm{R}^{2}=0.247$, and the best fit line was given by the equation:

[6] Yield stress $(\mathrm{MPa})=68.5-35.8 r-9.27 w$

where $w$ is the proportional width of the bark inclusion at the apex of the bifurcation when compared with the width of the parent stem (as a percentage, no maximum limit). The diameter ratio predicted $16.6 \%$ of the variability in the sample, the width 
of the bark inclusion a further $8.1 \%$ using this model (Equation 6). When the factor of parent stem diameter was added to this second regression model, it again did not significantly improve the prediction of breaking strength $\left(\mathrm{t}_{83}=0.67 ; P=0.502\right)$.

The mean maximum breaking stress $\left(\sigma_{\text {fmax }}\right)$ of normally formed bifurcations ( $\mathrm{n}=135)$ was 46.9 $\mathrm{MPa}( \pm 0.8 \mathrm{SE})$, the mean maximum breaking stress for bifurcations with embedded bark $(\mathrm{n}=17)$ was 44.7 ( $\pm 1.79 \mathrm{SE})$, whereas the mean breaking stress for cupshaped bark-included bifurcations $(\mathrm{n}=57)$ was $37.02( \pm 1.11$ $\mathrm{SE}) \mathrm{MPa}$, and for those with bark at their apex $(n=30)$, the mean was $27.22( \pm 1.23 \mathrm{SE}) \mathrm{MPa}$. A GLM ANOVA with the parent stem diameter as a covariate $\left(\mathrm{F}_{2,236}\right.$ $=49.4 ; P<0.0001)$ and tree number as a random variable showed that there were significant differences between these four groups, and a post hoc Tukey test $(\mathrm{CI}=$ 95\%) showed that both the cup-shaped, bark-included bifurcations and the wide-mouthed bark inclusions had significantly different mean breaking stresses from each other and from the normally formed bifurcations and those with embedded bark (Figure 9). Parent stem diameter was not a significant covariate that affected bifurcation strength $\left(\mathrm{F}_{2,236}<0.01 ; P=0.989\right)$, nor was tree number a significant variable.

\section{DISCUSSION}

The results from this study show there are gradations in the strength of bark-included bifurcations in young hazel plants that relate to the scale and position of the bark inclusion and their level of occlusion within the wood formed at these bifurcations. These factors were found to be independent

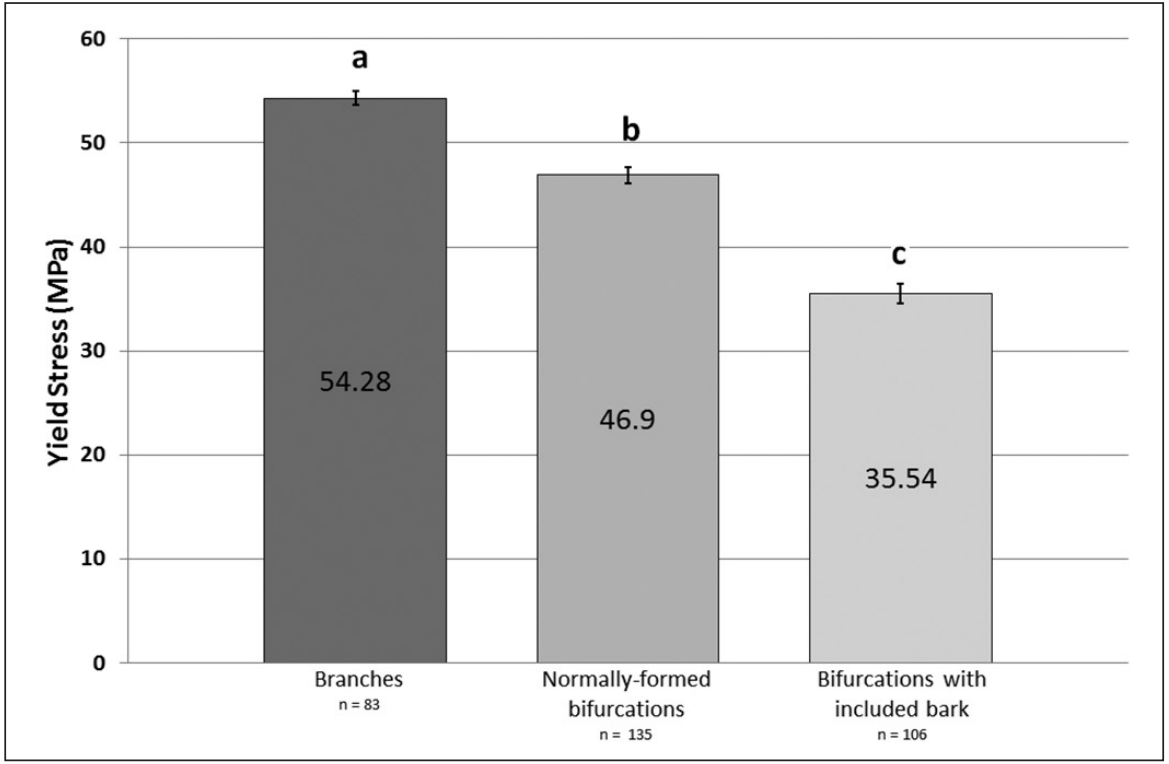

Figure 8. Mean yield stress of branches with normally formed bifurcations and bifurcations with included bark. Columns labeled with different letters are significantly different, as determined by a one-way ANOVA and post hoc Tukey test (Cl: 95\%).

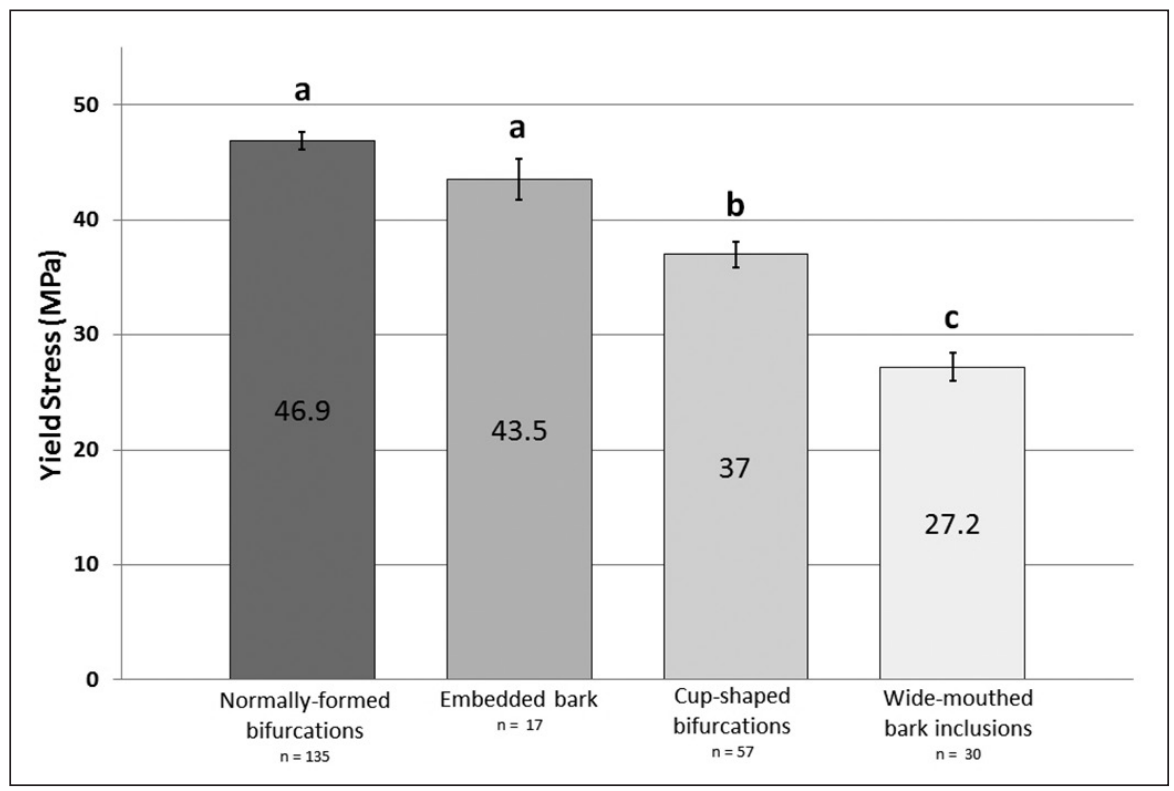

Figure 9. Mean yield stress of normally formed bifurcations, bifurcations with embedded bark, cup-shaped bifurcations, and bifurcations with wide-mouthed bark inclusions at their apices. Columns labeled with different letters are significantly different, as determined by a GLM ANOVA and post hoc Tukey test (CI: 95\%).

of the size of the specimens, where this was assessed by recording the diameter of the parent stems just below the bifurcation (which varied from $17.01 \mathrm{~mm}$ to $58.69 \mathrm{~mm}$ ). However, there was considerable variability in the sample that remains unexplained from the simple regression models used here, which explained only a quarter of the variation in strength found in the sample bifurcations. 
Firstly, it is clear the diameter ratio of the branches has a greater influence on the strength of hazel bifurcations in static rupture tests than does the extent of the bark inclusions. In both normally formed and bark-included bifurcations, those consisting of two branches of similar diameter were weaker and were more likely to fail by Type II failure mode than those with a lower diameter ratio. Secondly, the presence of a bark-inclusion weakened hazel bifurcations to a similar degree as was found by Smiley (2003) in Acer rubrum, and that the extent of weakening increased with the width of the bark inclusion at the apex of the bifurcation. However, there was still a large degree of variability in this sample, so accurate predictions about the strength of a bifurcation cannot be made simply from examination of this aspect of its external morphology. The variability may be mainly due to differences in the reorientation of wood grain at the apices of the bifurcations, as this provides a key strengthening component (Slater et al. 2014).

Diameter ratio can have a significant effect on the failure mode of bifurcations in trees (Gilman 2003; Kane et al. 2008). In the case of these hazel samples, boundaries for different failure modes can be set by their diameter ratios. For the samples tested, a diameter ratio higher than $80 \%$ most frequently resulted in Type II failure mode, a lower ratio than that led to most of the Type I failure modes until the ratio of $72 \%$ was reached, where branch failures started occurring and only branch failures occurred at a ratio of $55 \%$ and below. It should be noted that the bifurcations of hazel were selected to have a relatively high diameter ratio between their two branches so as to successfully investigate bifurcation failures; consequently the incidence of branch failures was low in the test specimens.

Type I failures of bifurcations showed a greater displacement prior to yielding than did Type II failures (Figure 7). This is explained by the initial stage of Type I failure, where wood at the outer edge of the bifurcation is yielding under compression until sufficient stress is concentrated at the bifurcation apex to split the xylem tissues situated there. Branch failures, using this form of rupture test, displayed a much extended displacement during testing, as there was a great deal of yielding under compression on the underside of the branch prior to any break of fibers under tension on the upper side (van Casteren and Ennos 2010). The force/displacement graphs often showed a different behavior where a bark inclusion was present, with a longer phase of plastic deformation as the bifurcation 'crept apart' rather than exhibiting a distinct breaking point. However, for those exhibiting Type II failure mode, the peak force was reached with less displacement in bark-included bifurcations than with normally formed bifurcations. The absence of interlocking wood grain at the apex of these bark-included bifurcations is an obvious reason for this difference in mechanical behavior (Slater et al. 2014). These results corroborate the findings of Pfisterer (2003), who also found differences in behavior in hazel bifurcations with and without bark inclusions, but who did not differentiate between Type I and Type II failure modes.

Gilman (2003) ascribed the higher tensile strength of bifurcations with a higher diameter difference in their branches to the level of occlusion of the smaller branch into the other stem. However, it may be more appropriate to think about this relationship in terms of the loading caused by the different bending behaviors of the branches in the wind (Figure 10).

From preliminary research work the authors have undertaken using accelerometers attached

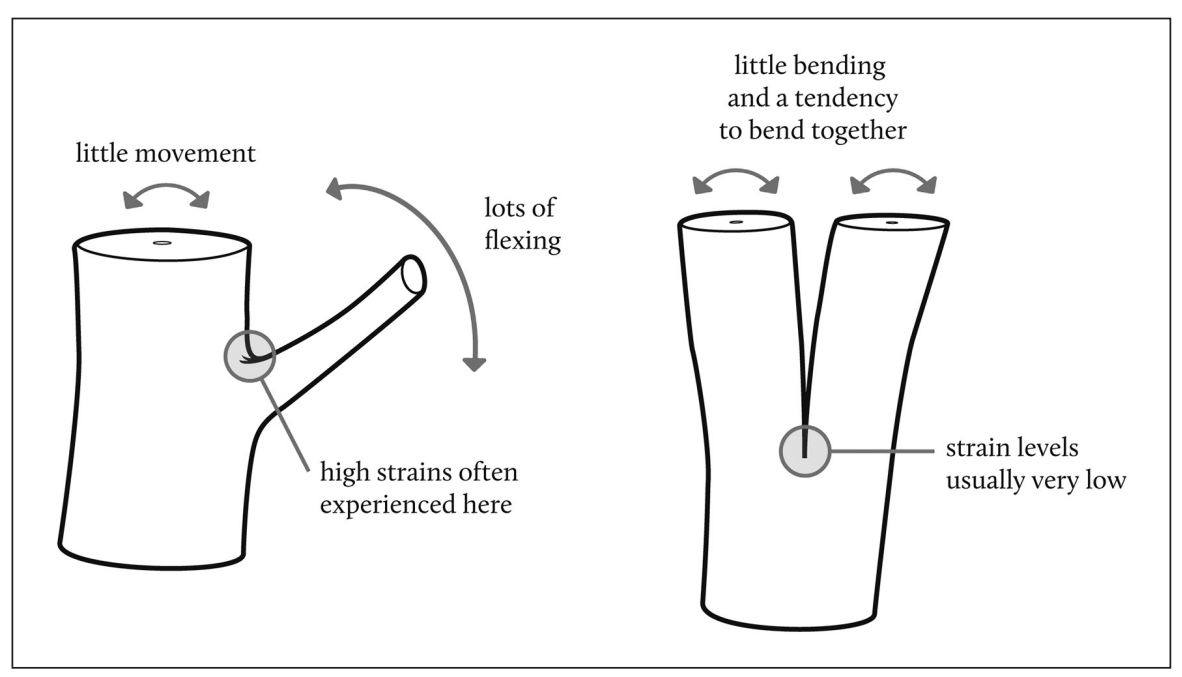

Figure 10. Suggested contrast in bending behavior between a low-diameter ratio bifurcation and a high-diameter ratio bifurcation. 
just above bifurcations in hazel, the frequency and extent of oscillations separating a smaller diameter branch and a larger diameter branch, where their bases are conjoined at a bifurcation, will both be greater than when two branches of equal diameter are bent in a wind of the same force. As a consequence of experiencing higher strain levels more regularly at its apex through this different bending behavior, lower diameter ratio bifurcations are likely to develop a higher level of modification of their tissues to adequately resist those forces (Metzger 1893; Jaffe and Forbes 1993; Telewski 1995). In contrast, the bifurcation with included bark is a structure where little to no strain is regularly experienced at its apex, so no substantial resources are committed by the tree to reinforcing it.

On average, bifurcations with bark inclusions were only three-quarters the strength of the normally formed specimens, but there was a wide range of peak stress values, with some barkincluded samples experiencing branch failure rather than splitting at the bifurcation itself and other bark-included bifurcations having less than $40 \%$ of the bending strength of the smaller branch.

A simple analysis of the strength of the bifurcations with included bark and their morphology provided two useful insights. Firstly, it can be concluded that small areas of embedded bark do not give rise to a significant difference in bifurcation strength. Secondly, cup-shaped bifurcations in hazel were significantly stronger than those that had bark at their apex. The conclusion from these findings is that the main reason why the strength of bifurcations with included bark was found to be so variable in the tested specimens was that the areas of included bark in the samples were at different stages of occlusion at the bifurcation apex; a higher level of occlusion of the bark inclusion resulted in an increase in the bifurcation's strength. Thus, the cup-shaped bifurcations tested in this study represented different stages of repair of the structural flaw that was caused by the initial inclusion of bark into those junctions.

From this experiment, the authors can provide an interpretation of the mechanical performance of bifurcations with included bark in trees; however, it is very important to recognize the limitation of this study in that young bifurcations of only one species (Corylus avellana L.) that contained solely juvenile wood were tested, and the mechanical behavior of mature bifurcations in different woody species may well vary from what was found in this study's samples.

Wide-angled bifurcations, which are U-shaped at their apex and without bark inclusions, and bifurcations with embedded bark should both be considered adequate structures, as there should be interlocking wood grain present at the bifurcation apex. Where a significant width of included bark is found at the apex of the bifurcation, this indicates a significantly weaker bifurcation, and a tree assessor should evaluate the proportional width of this bark in relation to the overall width of the join perpendicular to the plane of the bifurcation. They should also take into account the extent of adaptive growth at each side of the bifurcation, account for the extent of occlusion of the bark inclusion by the formation of a cup-shaped bifurcation, and most critically, take into account whether the level of wind exposure of the bifurcation has been heightened by recent site changes or pruning work. The rapid formation of additional xylem that lies at either side of a bifurcation (often indicated by a change in bark texture) may be an indication of instability of that bifurcation (Mattheck and Breloer 1994).

Features that tree assessors should survey in bark-included bifurcations, based on this study using hazel specimens, are identified in Figure 11.

It would seem that a bark-included bifurcation's notoriety as a defect in trees comes from the risk of this structure being exposed to a wind event or other loading event that causes the two arising branches to oscillate or move apart in a way that has not frequently occurred during the bifurcation's prior development. This problem can be compounded by arboricultural practices, like crown thinning, the felling of adjacent trees, or the transplanting of trees into new locations, where these practices would lead to abrupt changes in the level of exposure to which the bifurcation is not sufficiently adapted (Wood 1995).

Studies of the strength of bifurcations with included bark in trees should be taken further. As in this study, researchers tested juvenile wood in only one species (Corylus avellana L.); a similar study using mature bifurcations in a range of species would assist in determining their mechanical behavior. In addition, a better understanding of 


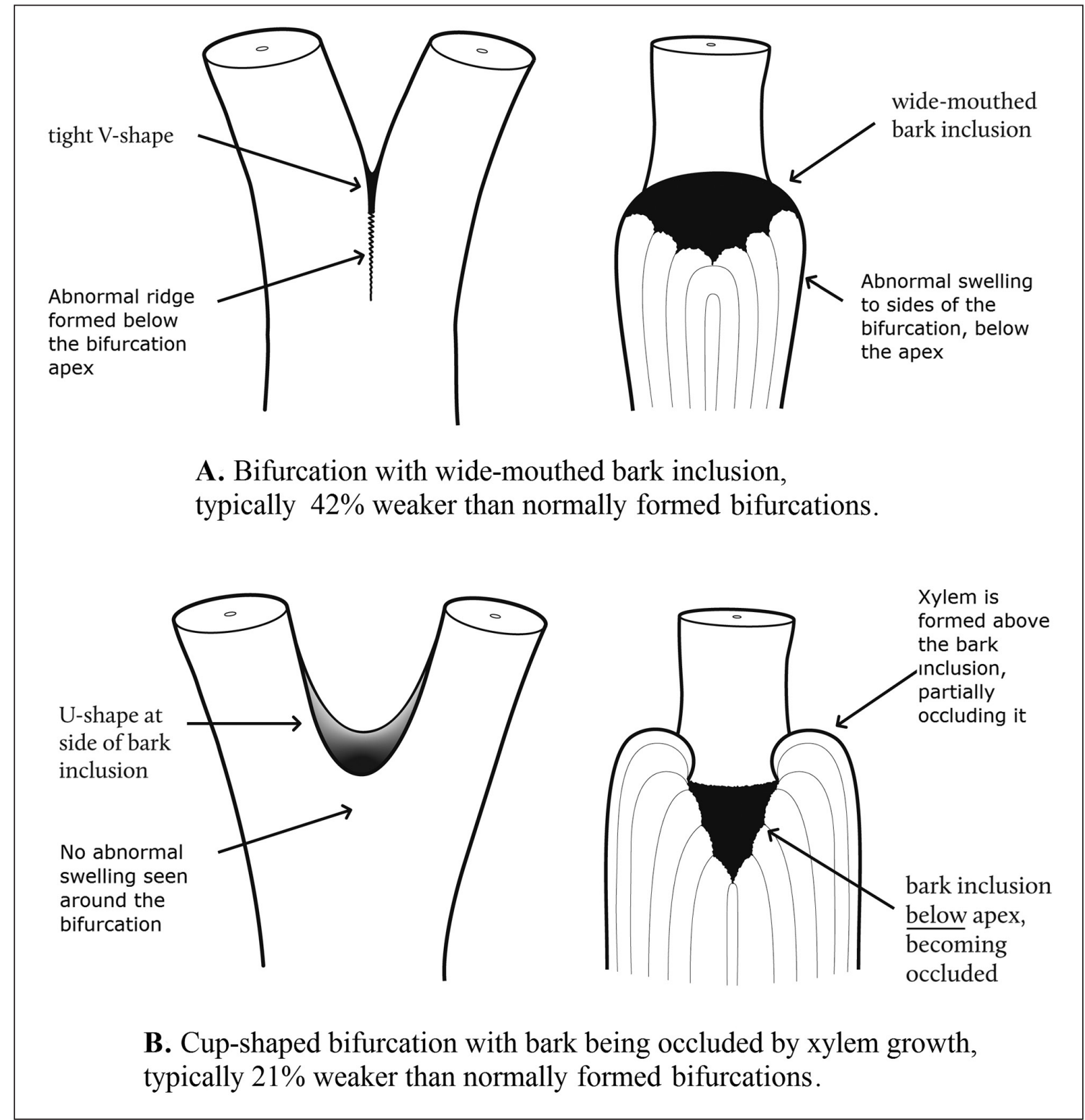

Figure 11. Weaker and stronger forms of bifurcations with included bark: a) a wide-mouthed bark inclusion positioned at the apex of the bifurcation, with acutely pointed reaction growth forming below the inclusion; b) a cupshaped bifurcation with two rounded areas of abnormal growth at the apex of the bifurcation that act to resist bending stresses.

the forces affecting the modulus of rupture of these bifurcations may come from using finite element analysis to assess stress concentration levels at the apices of such bifurcations. Further study should also determine how frequently, and under what particular wind conditions, such damaging oscillations occur to bifurcations with included bark. It would also be informative to investigate the movement behavior of normally formed bifurcations during dynamic wind loading and to deter- mine to what extent these bifurcations develop their morphology and wood properties in relation to the dynamic forces that act upon them.

Acknowledgments. This research work was sponsored by Myerscough College, Lancashire, UK, and supported by staff at the University of Manchester, England.

For the provision of the hazel specimens used in this experiment, the authors' thanks are given to Mike Carswell.

Assistance in the production of figures was kindly given by Mike Heys of Myerscough College. 


\section{LITERATURE CITED}

Abramoff, M.D., P.J. Magalhaes, and S.J. Ram. 2004. Image Processing with ImageJ. Biophotonics International 11(7):36-42.

Gere, J.M., and S.P. Timoshenko. 1996. The Mechanics of Materials, fourth edition. PWS Publishing Co., Boston, Massachusetts, U.S.

Gilman, E. 2003. Branch-to-stem diameter ratio affects strength of attachment. Journal of Arboriculture 29(5):291-294.

Gilman, E. 2011. An Illustrated Guide to Pruning, third edition. Cengage Learning, Independence, Kentucky, U.S. 352 pp.

Harris, R.W., J.R. Clark, and N.P. Matheny. 2004. Arboriculture: Integrated Management of Landscape Trees, Shrubs, and Vines, fourth edition. Prentice-Hall, New Jersey, U.S.

Helliwell, R. 2004. A discussion of the failure of weak forks. Arboricultural Journal 27:245-249.

Jaffe, M.J., and S. Forbes. 1993. Thigmomorphogenesis: The effect of mechanical perturbation on plants. Plant Growth Regulation 12:313-324.

Kane, B., R. Farrell, S.M. Zedaker, J.R. Loferski, and D.W. Smith. 2008. Failure mode and prediction of the strength of branch attachments. Arboriculture \& Urban Forestry 34(5):308-316.

Lonsdale, D. 1999. Principles of Tree Hazard Assessment and Management, first edition. The Stationery Office Books, London, UK. 388 pp.

Lonsdale, D. 2000. Hazards from trees: A general guide. Forestry Commission Practical Guide series. Forestry Commission.

Matheny, N.P., and J.R. Clark. 1994. Evaluation of Hazard Trees in Urban Areas, second edition. International Society of Arboriculture, Champaign, Illinois, U.S.

Mattheck, C., and H. Breloer. 1994. The Body Language of Trees: A Handbook for Failure Analysis. The Stationery Office, London, UK. 240 pp.

Metzger, K. 1893. Der wind als massgebender factor für das waschstum der bäume. Mündener Forstliche Hefte 3:35-86.

Pfisterer, J.A. 2003. Towards a better understanding of tree failure: Investigations into bending stresses of branch junctions and reiterates of European filbert (Corylus avellana L.) as a model organism. In: Second International Symposium on Plant Health in Urban Horticulture, August 27-29, 2003. Berlin, Germany.

Shigo, A.L. 1989. Tree pruning: A worldwide photo guide. Shigo and Trees Associates, Durham, New Hampshire, U.S. pp. 78-83.

Slater, D., and A.R. Ennos. 2013. Determining the mechanical properties of hazel forks by testing their component parts. Trees: Structure and Function 27(6):1515-1524.

Slater, D., R.S. Bradley, P.J. Withers, and A.R. Ennos. 2014. The anatomy and grain pattern in forks of hazel (Corylus avellana L.) and other tree species. Trees: Structure and Function 28(5):1437-1448.

Smiley, E.T. 2003. Does included bark reduce the strength of codominant stems? Journal of Arboriculture 29(2):104-106.

Telewski, F.W. 1995. Wind-induced physiological and developmental responses in trees. pp. 237-263. In: M.P. Coutts and J. Grace (Eds.). Wind and Trees. Cambridge University Press, Cambridge, UK.

van Casteren, A., and A.R. Ennos. 2010. Transverse stresses and modes of failure in tree branches and other beams. Proceedings of the Royal Society B. Biological Sciences 277(1685):1253-1258.

Wood, C.J. 1995. Understanding wind forces on trees. pp. 133-163. In: M.P. Coutts and J. Grace (Eds.). Wind and Trees. Cambridge University Press, Cambridge, UK.
Duncan Slater (corresponding author)

Senior Lecturer in Arboriculture

Myerscough College

St. Michaels Road

Bilsborrow, Preston PR3 ORY

phone: $01995642222 \times 2304$

fax: 01995642333

email: dslater@myerscough.ac.uk

Roland Ennos

School of Biological, Biomedical, and Environmental Sciences

University of Hull

Cottingham Road

Kingston-upon-Hull HU6 7RX

email: R.Ennos@hull.ac.uk

Résumé. Les fourches d'arbres présentant de lécorce incluse sont considérés comme un défaut en raison de l'écorce qui affaiblit l'union entre les branches. Dans le but d'évaluer plus précisément cet effet d'affaiblissement, 241 fourches de jeunes spécimens de noisetiers (Corylus avellana L.), dont 106 présentaient de l'écorce incluse, ont été récoltées et soumises à des tests de rupture. La flexion en trois points des petites branches servit comme point de référence pour la résistance relative des fourches.

Les embranchements avec écorce incluse se rompaient lorsque les mouvements étaient plus amplifiés et leur coefficient de rupture était de $24 \%$ inférieur à celui des fourches normalement formées, tandis que la régression graduelle montrait que les meilleurs indices de résistance dans ces fourches à écorce incluse étaient le ratio du diamètre des deux branches et la largeur de lécorce incluse, ce qui expliquait respectivement $16,6 \%$ et $8,1 \%$ de la variabilité. Les fourches avec écorce incluse, en forme de bol, où lécorce incluse était partiellement limitée par la présence de xylème ont été évaluées en moyenne $36 \%$ plus résistantes que celles où l'écorce incluse se trouvait au sommet de la fourche.

Ces résultats montrent que la résistance des fourches à écorce incluse varie significativement chez les jeunes noisetiers en lien direct avec le niveau d'occlusion de l'écorce dans la fourche. Il peut donc être possible d'évaluer l'ampleur de la déficience qu'une fourche à écorce incluse présente dans un arbre en évaluant le niveau relatif d'occlusion de l'écorce incluse.

Zusammenfassung. Eingewachsene Rinde wird bei Bäumen als ein Schaden betrachtet, weil die Rinde die Verbindung zwischen den Ästen schwächt. Für eine präzisere Untersuchung dieses Schwäche-Effekts wurden 241 Bifurkationen con jungen Haselnusssträuchern (Corylus avellana L.), von denen 106 eingewachsene Rinde aufwiesen, geerntet und einem Reisstest unterzogen. Als Benchmark für die relative Stärke dieser Bifurkationen wurde eine Drei-Punkt-Biegung an den schmaleren Ästen angenommen.

Bifurkationen mit eingewachsener Rinde versagten an höheren Abständen und ihr Bruch-Modus lag um 24 \% niedriger als bei normal geformten Bifurkationen, während eine schrittweise Regression zeigte, dass die beste Vorhersage von Stärke bei den Bifurkationen mit eingewachsener Rinde die durchschnittliche Durchmesser und die Weite der Rindeninklusion war, welches die Variabilität von 16,6\% bzw. 8,1 \% erklärt. Bifurkationen mit eingewachsener Rinde und Taschenbildung, wo die eingeschlossene Rinde teilweise durch Zylem verdeckt war, waren durchschnittlich $36 \%$ stärker als solche, wo die eingeschlossene Rinde an dem Scheitelpunkt der Bifurkation auftrat.

Diese Ergebnisse zeigen, dass es signifikante Abweichungen bei der Stärke von Bifurkationen mit eingewachsener Rinde bei jungen Haselsträuchern gibt, die direkt mit dem Grad des Einschlusses von 
Rinde in die Vergabelung verbunden sind. Es könnte daher möglich sein, das Ausmaß des Schadens, welches eine Bifurkation mit eingewachsener Rinde bei einem Baum ausmacht, zu untersuchen, indem man den relativen Anteil des Einschlusses der eingewachsenen Rinde untersucht.

Resumen. Las uniones con corteza incluida en los árboles se consideran un defecto porque la corteza debilita la unión entre las ramas. Para evaluar con mayor precisión este efecto de debilitamiento, 241 bifurcaciones de ejemplares jóvenes de avellano (Corylus avellana L.), de los cuales 106 tenían inclusiones de corteza, fueron cosechadas y sometidas a pruebas de ruptura. Tres puntos de flexión de las ramas más pequeñas actuaron como referencia para medir la fuerza relativa de las bifurcaciones.

Las bifurcaciones con corteza incluida fallaron con desplazamientos más altos y su módulo de ruptura fue $24 \%$ menor que las bifurcaciones formadas normalmente, mientras que el análisis de regresión mostró que los mejores predictores de la fuerza en estas bifurcaciones con corteza-incluida fueron el diámetro y el ancho de la corteza incluida, que explicó el $16,6 \%$ y el $8,1 \%$ de la variabilidad, respectivamente. Las bifurcaciones de corteza incluida en forma de copa parcialmente ocluida por el xilema, en promedio, son $36 \%$ más fuertes que aquellas en los que la corteza incluida estaba situada en el vértice de la bifurcación.

Estos hallazgos muestran que hay gradaciones significativas en la fuerza de las bifurcaciones con corteza incluida en avellanos juveniles, que se relacionan directamente con el nivel de la oclusión de la corteza. Por lo tanto, es posible evaluar la magnitud del defecto que una bifurcación con corteza incluida representa en un árbol mediante la evaluación del nivel relativo de la oclusión de la corteza incluida. 